\title{
PENGARUH UPAH, PENGALAMAN KERJA DAN SEMANGAT KERJA TERHADAP PRODUKTIVITAS KARYAWAN PADA PT. LINGGA TIGA SAWIT SIGAMBAL
}

\author{
Imas Yuningsih ${ }^{1}$, Efendi Pasaribu ${ }^{2}$ \\ ${ }^{1}$ Alumni Sarjana Ekonomi STIE Labuhanbatu \\ ${ }^{2}$ Dosen STIE Labuhanbatu
}

\begin{abstract}
Abstrak
Tujuan penelitian ini adalah: 1) Untuk mengetahui pengaruh upah terhadap produktivitas karyawan pada PT. Lingga Tiga Sawit Sigambal, 2) untuk mengetahui pengaruh pengalaman kerja terhadap produktivitas karyawan pada PT. Lingga Tiga Sawit Sigambal dan untuk mengetahui pengaruh semangat kerja terhadap produktivitas karyawan pada PT. Lingga Tiga Sawit Sigambal. Hipotesis penelitian adalah variabel upah berpengaruh signifikan terhadap produktivitas karyawan pada PT. Lingga Tiga Sawit Sigambal, variabel pengalaman kerja berpengaruh signifikan terhadap produktivitas karyawan pada PT. Lingga Tiga Sawit Sigambal dan variabel semangat kerja berpengaruh terhadap produktivitas karyawan pada PT. Lingga Tiga Sawit Sigambal. Populasi dari penelitian ini adalah karyawan pada PT. Lingga Tiga Sawit Sigambal. Jumlah populasinya adalah sebanyak 39 responden. Hasil penelitian menunjukkan bahwa: 1) upah berpengaruh positif dan signifikan terhadap produktivitas karyawan pada PT. Lingga Tiga Sawit Sigambal, pengalaman kerja berpengaruh positif dan signifikan terhadap produktivitas karyawan pada PT. Lingga Tiga Sawit Sigambal dan semangat kerja berpengaruh positif dan signifikan terhadap produktivitas karyawan pada PT. Lingga Tiga Sawit Sigambal.
\end{abstract}

Kata kunci: Upah, Pengalaman kerja, Semangat kerja, Produktivitas karyawan

\section{PENDAHULUAN}

Manusia merupakan salah satu faktor produksi yang perlu diberikan motivasi untuk selalu meningkatkan produktivitas, karena produktivitas sangat diperlukan bagi perusahaan yang banyak mempekerjakan tenaga kerja manusia sebagai faktor utama bagi perusahaan, maka sumber daya manusia sangatlah penting meskipun perkembangan tehnologi semakin modern. Tenaga kerja merupakan salah satu fungsi operasional dalam mencapai tujuan yang diinginkan, tenaga kerja juga merupakan faktor kunci keberhasilan perusahaan dalam menigkatkan produktivitas kerja.

PT. Lingga tiga sawit merupakan perusahaan yang bergerak dibidang produksi sawit yang rata-rata dikerjakan oleh lebih dari satu orang yang terbagi menurut spesifikasi pekerjaan, sehingga untuk menghitung jumlah produk yang dihasilkan oleh seorang karyawan tidak dapat diketahui dengan pasti.

Banyak indikator yang mempengaruhi tingkat produktivitas kerja karyawan, diantaranya adalah upah, pengalaman kerja dan semangat kerja. Perusahaan harus bisa menetapkan suatu imbalan jasa dalam betuk upah sesuai dengan kebutuhan hidup dan pengalaman kerja. Tentu saja harus disesuaikan dengan kemampuan perusahaan. Seseorang akan bekerja lebih giat apabila mempunyai semangat kerja yang tinggi. 
Motivasi dalam hal ini berarti bahwa semangat untuk berperan aktif dalam proses produksi bagi seorang karyawan, ditentukan oleh jenis motivasinya. Tanpa adanya motivator yang menjadi penggerak, maka motivasi karyawan untuk bekerja secara produktif tidak akan terjadi. Motivasi yang menjadi penggerak motivator meliputi prestasi, penghargaan, tantangan, tanggung jawab. Selain unsur-unsur motivator tersebut masih ada faktor-faktor lain yang berpengaruh terhadap produktivitas kerja yaitu imbalan jasa, kebijaksanaan perusahaan, supervisi, hubungan antar manusia, rasa aman, ligkungan kerja dan status.

Penghargaan dan imbalan jasa merupakan salah satu motivator yang menjadi penggerak kerja karyawan. Yang dimaksud penghargaan disini adalah penghargaan atas prestasi yang telah dicapai. Seseorang akan memberikan kepuasan batin dalam bentuk materi, uang bonus maupun yang berbentuk barang. Sedangkan imbalan jasa atau upah yang dapat menjamin pemenuhan kebutuhan fisik minimum merupakan salah satu syarat mutlak untuk mengharapkan adanya produktivitas tenaga kerja.

Bagi perusahaan sedapat mungkin memberikan upah diatas kebutuhan fisik minimal karyawan. Hal ini bertujuan untuk menghindari adanya produktivitas kerja yang rendah.

Selain upah dan pelatihan kerja, pengalaman kerja juga mempengaruhi produktivitas kerja karyawan. Orang dikatakan telah mempunyai pengalaman kerja apabila orang tersebut telah menjalani atau mengetahui sesuatu yang berkaitan dengan pekerjaan. Karyawan yang melakukan aktivitas dalam perusahaan harus melaksanakan apa yang menjadi tugas dan kewajiban. Apabila para kayawan telah melakukan aktivitasnya, maka karyawan tersebut dikatakan karyawan yang sudah mempunyai pengalaman kerja. Dengan pengalaman kerja yang tinggi diharapkan dapat meningkatkan produktivitas kerja karyawan.

Dengan pengalaman kerja, maka perusahaan tidak perlu lagi melaksanakan training. Atau bila training itu perlu dilaksanakan adalah sekedarnya saja. Ada juga perusahaan yang menyeleksi pengalaman seorang karyawan sebagai sesuatu hal yang penting, sebab dengan dapat diterimanya orang-orang yang berpengalaman dapat ditemukan ide-ide baru bagi perusahaan yang menerimanya.

Tingkat keahlian seseorang dapat dihubungkan dengan pengalaman kerjanya, artinya dengan pengalaman yang banyak berarti keahliannya juga cukup tinggi. Kesanggupan untuk dapat menyelesaikan suatu tugas tertentu dengan berhasil tidak saja ditentukan oleh pengalaman, akan tetapi lebih banyak dipengaruhi oleh inteligensia seseorang. Kenyataan, menunjukkan bahwa ada kecenderungan makin lama bekerja makin banyak pengalaman kerja yang dimiliki oleh tenaga kerja yang bersangkutan. Sebaliknya makin singkat masa kerja maka makin sedikit pengalaman kerja yang diperoleh. Orang dikatakan telah mempunyai pengalaman kerja apabila orang tersebut telah menjalani atau mengetahui sesuatu yang berkaitan dengan pekerjaan.

Jadi pengalaman kerja yaitu kemampuan atas segala sesuatu yang telah diperoleh dan dimiliki oleh para karyawan melalui aktivitas jasmani yang biasanya ditunjukkan dalam masa kerja. Dalam sebuah usaha diharapkan dapat menghasilkan produktivitas kerja yang tinggi, untuk itu para karyawan perlu mempunyai pengalaman kerja yang cukup. Apabila karyawan belum mempunyai

pengalaman kerja, perusahaan dapat mengadakan pelatihan kerja agar karyawan lebih siap dan mampu melaksanakan pekerjaaan dengan sebaik-baiknya. 
Faktor lain yang mempengaruhi produktivitas kerja adalah upah, apabila upah yang diberikan oleh perusahaan sesuai dengan yang diharapkan oleh karyawan dan mampu memenuhi kebutuhan karyawan, maka karyawan akan merasa kerja kerasnya dihargai dan diterima baik oleh perusahaan dan secara otomatis produktivitas kerja dapat lebih ditingkatkan. Karyawan pada perusahaan ini sebagian besar juga telah cukup berpengalaman dibidangnya masing-masing. Tetapi sebagian karyawan merasa upah yang diberikan oleh perusahaan kurang sesuai dengan apa yang mereka harapkan. Sehingga produktivitas kerja yang dicapai juga kurang maksimal karena karyawan merasa perusahaan kurang memperhatikan kebutuhan karyawannya.

Demikian upah, pengalaman kerja dan semangat kerja memberi peluang terhadap karyawan agar dapat berperan dalam perusahaan. Atas dasar itulah, penulis tertarik untuk meneliti judul masalah ini "Pengaruh upah, pengalaman kerja dan semangat kerja terhadap produktivitas karyawan pada PT. Lingga Tiga Sawit Sigambal”.

\section{LANDASAN TEORI}

\section{Upah}

Menurut Undang-Undang Republik Indonesia Nomor 13 tahun 2003 Tentang Ketenagakerjaan. Dalam Bab I Pasal 1 angka 30 dijelaskan Upah adalah hak pekerja/buruh yang diterima dan dinyatakan dalam bentuk uang sebagai imbalan dari pengusaha atau pemberi kerja kepada pekerja/buruh yang ditetapkan dan dibayarkan menurut suatu perjanjian kerja, kesepakatan, atau peraturan perundang-undangan, termasuk tunjangan bagi pekerja/buruh dan keluarganya, atas suatu pekerjaan dan/atau jasa yang telah atau akan dilakukan.

\section{Pengalaman Kerja}

Pengalaman kerja adalah proses pembentukan pengetahuan atau keterampilan tentang metode suatu pekerjaan karena keterlibatan karyawan tersebut dalam pelaksanaan tugas pekerjaan (Manulang, 2007).

Pendapat lain mengemukakan pengalaman kerja adalah ukuran tentang lama waktu atau masa kerja yang telah ditempuh seseorang dapat memahami tugas - tugas suatu pekerjaan dan telah melaksanakan dengan baik (Ranupandojo, 2008).

Menurut Trijoko, pengalaman kerja adalah pengetahuan atau keterampilan yang telah diketahui dan dikuasai seseorang yang akibat dari perbuatan atau pekerjaan yang telah dilakukan selama beberapa waktu tertentu (Trijoko, 2006). Dari uraian tersebut dapat disimpulkan, bahwa pengalaman kerja adalah tingkat penguasaan pengetahuan serta keterampilan seseorang dalam pekerjaannya yang dapat diukur dari masa kerja dan dari tingkat pengetahuan serta keterampilan yang dimilikinya.

\section{Semangat kerja}

Upaya pencapaian tujuan operasional masalah semangat kerja pegawai tidak dapat diabaikan begitu saja karena pegawai perupakan faktor yang sangat penting disamping faktor-faktor lainnya. Oleh karena itu semangat kerja pegawai perlu dipupuk dan ditingkatkan demi tercapainya tujuan organisasi secara efektif dan efisien. Leighten dalam Moekijat (2007) menyatakan bahwa semangat atau motif kerja adalah kemampuan sekelompok orang untuk bekerjasama dengan giat dan konsekuen dalam mengejar tujuan bersama, bekerjasama menekankan dengan tegas hakekat saling berhubungan dari suatu kelompok dengan keinginan yang nyata untuk bekerjasama. Dengan giat dan konsekuen 
menunjukkan caranya untuk sampai pada tujuan melalui disiplin bersama. Tujuan bersama menjelaskan pada tujuannya adalah satu yang mereka inginkan.

\section{Produktivitas kerja}

Menurut Jhon Newstrom (2006) mengemukakan bahwa: productivity is achieving quantity anf quality of result while controlling inputs in order to develop the capacity to progress. (produktivitas adalah meraih hasil kualitas dan kuantitas masukan dalam rangka membangun kapasitas untuk kemajuan). Menurut Greenberg dalam Muchdarsyah (2006) mengatakan bahwa: "Produktivitas dapat diartikan sebagai "ratio antara hasil karya nyata (output) dalam bentuk barang danjasa, dengan masukan (input) yang sebenarnya".

\section{HASIL PENELITIAN}

\section{Analisis Regresi Linier berganda}

Analisis regresi linier berganda digunakan untuk mengetahui pengaruh atau hubungan variable bebas terhadap variabel terikat. Analisis regresi dalam penelitian ini menggunakan metode kuadrat terkecil. Adapun hasil pengujiannya dapat dilihat dibawah ini :

Tabel 1. Regresi Linier Berganda

Coefficients $^{\mathrm{a}}$

\begin{tabular}{|c|c|c|c|c|c|c|}
\hline \multirow{2}{*}{\multicolumn{2}{|c|}{ Model }} & \multicolumn{2}{|c|}{ Unstandardized Coefficients } & \multirow{2}{*}{$\begin{array}{c}\begin{array}{c}\text { Standardized } \\
\text { Coefficients }\end{array} \\
\text { Beta }\end{array}$} & \multirow[b]{2}{*}{$\mathrm{T}$} & \multirow[b]{2}{*}{ Sig. } \\
\hline & & $\mathrm{B}$ & Std. Error & & & \\
\hline \multirow[t]{4}{*}{1} & (Constant) & 1,279 & 2,141 & & 6,131 & 897 \\
\hline & Upah & ,091 & ,084 & ,081 & 4,075 & 000 \\
\hline & Pengalaman kerja & ,207 & ,129 &, 216 & 3,606 &, 000 \\
\hline & Semangat kerja & ,713 & ,138 & ,700 & 5,177 & ,000 \\
\hline
\end{tabular}

a. Dependent Variable: Produktivitas karyawan

dari hasil perhitungan diatas dapat dibuat sebuah model persamaan regresi linier berganda, yaitu sebagai berikut :

$$
\mathrm{Y}=1,279+0,091 \mathrm{X}_{1}+0,207 \mathrm{X}_{2}+0,713 \mathrm{X}_{3}
$$

\section{Koefisien Determinasi $\left(\mathbf{R}^{2}\right)$}

Pengujian koefisien determinasi $\left(\mathrm{R}^{2}\right)$, dlakukan untuk mengukur persentase kemampuan variabel bebas dalam menjelaskan perubahan variable terikat yaitu pada, dimana $0 \leq \mathrm{R}^{2} \leq 1$. 


\begin{tabular}{|l|r|r|r|r|}
\multicolumn{7}{|c|}{ Model Summary } \\
Model & R & R Square & $\begin{array}{c}\text { Adjusted R } \\
\text { Square }\end{array}$ & $\begin{array}{l}\text { Std. Error of } \\
\text { the Estimate }\end{array}$ \\
\hline 1 &, $897^{\mathrm{a}}$ &, 805 &, 789 & 1,355 \\
\hline
\end{tabular}

a. Predictors: (Constant), Semangat kerja, Upah, Pengalaman kerja

b. Dependent Variable: Produktivitas karyawan

Berdasarkan hasil perhitungan didapat nilai koefisien determinasi sebesar 0,805. Artinya $80,5 \%$ variabel terikat dijelaskan oleh variable bebas dan sisanya dijelaskan oleh variabel lain diluar variabel yang digunakan. Dengan demikian model regresi linier berganda ini layak dipakai dalam penellitian, karena sebagian besar variabel terikat dijelaskan oleh variabel-variabel bebas yang digunakan dalam model.

\section{Pengujian Hipotesis}

Uji parsial (uji t)

Tabel 3. Uji t

Coefficients $^{\mathrm{a}}$

\begin{tabular}{|l|r|r|r|r|r|}
\hline \multirow{2}{*}{ Model } & \multicolumn{2}{|c|}{$\begin{array}{c}\text { Unstandardized } \\
\text { Coefficients }\end{array}$} & $\begin{array}{c}\text { Standardize } \\
\mathrm{d} \\
\text { Coefficients }\end{array}$ & & \multirow{2}{*}{ T } \\
\cline { 2 - 5 } & \multicolumn{1}{|c|}{$\mathrm{B}$} & Std. Error & Beta & \multicolumn{1}{c|}{ Sig. } \\
\hline 1 (Constant) & 1,279 & 2,141 & & 6,131 &, 897 \\
Upah &, 091 &, 084 &, 081 & 4,075 &, 000 \\
Pengalaman kerja &, 207 &, 129 &, 216 & 3,606 &, 000 \\
Semangat kerja &, 713 &, 138 &, 700 & 5,177 &, 000 \\
\hline
\end{tabular}

a. Dependent Variable: Produktivitas karyawan

1) Pengujian hipotesis upah $\left(\mathrm{X}_{1}\right)$ terhadap produktivitas karyawan (Y). Hasil perhitungan diperoleh nilai t hitung $(4,075)>$ dari t tabel $(1,665)$ maka Ho ditolak dan Ha diterima, sehingga variabel upah berpengaruh secara tidak signifikan terhadap produktivitas karyawan pada PT. Lingga Tiga Sawit Sigambal.

2) Pengujian hipotesis pengalaman kerja $\left(\mathrm{X}_{2}\right)$ terhadap produktivitas karyawan $(\mathrm{Y})$. Hasil perhitungan diperoleh nilai t hitung $(3,606)>$ dari t tabel $(1,665)$ maka Ho ditolak dan Ha diterima, sehingga variabel pengalaman kerja berpengaruh secara signifikan terhadap produktivitas karyawan pada PT. Lingga Tiga Sawit Sigambal.

3) Pengujian hipotesis semangat kerja $\left(\mathrm{X}_{3}\right)$ terhadap produktivitas karyawan $(\mathrm{Y})$. Hasil perhitungan diperoleh nilai t hitung $(5,177)>$ dari $t$ tabel $(1,665)$ maka Ho ditolak dan Ha diterima, sehingga variabel semangat kerja berpengaruh secara signifikan terhadap produktivitas karyawan pada PT. Lingga Tiga Sawit Sigambal

Uji serentak (uji F)

Tabel 4. Uji F 


\begin{tabular}{|ll|c|c|c|c|c|}
\hline \multicolumn{2}{|c|}{ ANOVA $^{\mathrm{a}}$} \\
\hline \multicolumn{2}{|l|}{ Model } & $\begin{array}{c}\text { Sum of } \\
\text { Squares }\end{array}$ & df & Mean Square & F & Sig. \\
& Regression & 265,667 & 3 & 88,556 & 48,255 &, $000^{\mathrm{b}}$ \\
& Residual & 64,231 & 35 & 1,835 & & \\
& Total & 329,897 & 38 & & & \\
\hline
\end{tabular}

a. Dependent Variable: Produktivitas karyawan

b. Predictors: (Constant), Semangat kerja, Upah, Pengalaman kerja

Nilai $\mathrm{F}$ hitung $(48,255)>$ dari nilai $\mathrm{F}$ tabel $(2,47)$ dengan nilai signifikan $0,000<$ 0,05 maka Ho ditolak sehingga ada pengaruh yang signifikan upah, pengalaman kerja dan semangat kerja terhadap produktivitas karyawan pada PT. Lingga Tiga Sawit Sigambal.

\section{Pembahasan}

Dari hasil penelitian yang telah dilakukan penulis maka diperoleh kevalitan data kuesioner dan reliabilitas seluruh instrumennya. Nilai uji validitas diperoleh hasil $t_{\text {hitung }}>$ $\mathrm{t}_{\text {tabel}}$. Untuk reliabilitas instrument, kuesioner dinyatakan dapat digunakan untuk pengukuran dalam rangka pengumpulan data dikarenakan $r_{\text {hitung }}>r_{\text {tabel }}$ dan keputusan dinyatakan reliabel dan layak digunakan sebagai alat pengukuran dalam penelitian ini.

Hasil persamaan regresi diperoleh $\mathrm{Y}=1,270+0,091 \mathrm{X}_{1}+0,207 \mathrm{X}_{2}+0,713 \mathrm{X}_{3}$. Hasil koefisien determinasi diperoleh 0,805 . Artinya $85 \%$ variabel terikat (produktivitas karyawan) dijelaskan oleh variabel bebas dan sisanya dijelaskan oleh variabel lain diluar variabel yang digunakan.

Dengan pengujian dua sisi yang menggunakan tingkat signifikan sebesar $\alpha=5 \%$ dan dengan derajat kebebasan df $(\mathrm{n}-\mathrm{k}-1=39-2-1=36)$ diperoleh $t_{\text {tabel }}=1,684$. Hasil perhitungan pada regresi linier berganda diperoleh nilai $t_{\text {hitung }}$ sebesar 4,075. Dengan demikian $t_{\text {hitung }}$ lebih besar dari $t_{\text {tabel }}(4,075>1,684)$ maka $H_{0}$ ditolak $H_{A}$ diterima, artinya pada variabel upah secara parsial mempunyai pengaruh yang signifikan terhadap prouktivitas karyawan.

Nilai F hitung $(48,255)>$ dari nilai $F$ tabel $(2,47)$ dengan nilai signifikan $0,000<$ 0,05 maka Ho ditolak sehingga ada pengaruh yang signifikan upah, pengalaman kerja dan semangat kerja terhadap produktivitas karyawan pada PT. Lingga Tiga Sawit Sigambal.

\section{KESIMPULAN DAN SARAN Kesimpulan}

Berdasarkan data yang diperoleh dari hasil penelitian dapat disimpulkan bahwa:

1. Terdapat pengaruh positif dan signifikan upah terhadap produktivitas karyawan pada PT. Lingga Tiga Sawit Sigambal. Hal ini ditunjukkan dengan nilai t hitung variabel upah sebesar 4,075 lebih besar dari t tabel sebesar 1,665 dan nilai signifikansi sebesar 0,000 lebih kecil dari 0,05 .

2. Terdapat pengaruh positif dan signifikan pengalaman kerja terhadap produktivitas karyawan pada PT. Lingga Tiga Sawit Sigambal. Hal ini ditunjukkan dengan nilai thitung variabel pengalaman kerja sebesar 3,606 lebih besar dari t tabel sebesar 1,665 dan nilai signifikansi sebesar 0,000 lebih kecil dari 0,05. 
3. Terdapat pengaruh positif dan signifikan semangat Kerja terhadap produktivitas karyawan pada PT. Lingga Tiga Sawit Sigambal. Hal ini ditunjukkan dengan nilai thitung variabel disiplin kerja sebesar 5,177 lebih besar dari t tabel sebesar 1,665 dan nilai signifikansi sebesar 0,000 lebih kecil dari 0,05.

4. Terdapat pengaruh positif dan signifikan upah, pengalaman kerja dan semangat kerja secara bersama-sama terhadap produktivitas kerja. Hal ini ditunjukkan dengan nilai F hitung sebesar 48,255 lebih besar dari F tabel sebesar 2,47 dan nilai signifikansi sebesar 0,000 lebih kecil dari 0,05.

\section{Saran}

Berdasarkan pembahasan dan kesimpulan di atas, maka dapat diberikan saran sebagai berikut:

1. Produktivitas karyawan pada PT. Lingga Tiga Sawit Sigambal termasuk dalam kategori tinggi, maka pimpinan perusahaan perlu mempertahankan bahkan jika perlu menciptakan suasana kerja yang mampu merangsang produktivitas kerja yang lebih tinggi lagi. Hal tersebut dapat dilakukan dengan cara memperhatikan faktor-faktor yang mempengaruhi produktivitas kerja dan juga menanamkan rasa saling memiliki perusahaan, sehingga akan timbul rasa untuk ikut serta memelihara dan mempertahankan perusahaan.

2. Karyawan yang telah memiliki pengalaman kerja cukup harus memberikan bimbingan dan masukan kepada karyawan yang belum berpengalaman, sehingga mempermudah karyawan tersebut dalam bekerja.

3. Dalam proses perekrutan atau penerimaan tenaga kerja sebaiknya pimpinan perusahaan memperhatikan pengalaman kerja dari calon tenaga kerja. Sebab berdasarkan penelitian ini diketahui bahwa pengalaman kerja memiliki pengaruh yang dominan dalam peningkatan produktivitas kerja karyawan.

\section{DAFTAR PUSTAKA}

Bill Foster. 2007. Pembinaan Untuk Meningkatkan Kinerja Karyawan. Jakarta: PPM.

Fandy Tjiptono, 2009, Strategi Pemasaran. Edisi ke dua, penerbit Andi, Yogyakarta.

Handoko, T. Hani. 2008. Manajemen Personalia dan Sumber Daya Manusia. Yogyakarta : BPFE.

H.B. Siswanto. 2007. Pengantar Manajemen. Jakarta: Bumi Aksara

Jhon Newstrom, 2008. Perilaku dalam Organisasi. Jakarta: Bumi Aksara

Malayu. S.P. Hasibuan. 2009. Manajemen Sumber Daya Manusia. Jakarta: Bumi Aksara.

Manullang. M. 2007. Manajemen Personalia. Jakarta: Ghalia Indah.

Marwan Asri. 2006. Pengelolaan Karyawan. Yogyakarta: BPFE.

Matutina, 2006, Manajemen Sumber daya Manusia, cetakan kedua, Gramedia Widia Sarana Indonesia, Jakarta. 
Muchdarsyah Sinungan. 2006. Produktivitas Apa dan Bagaimana. Jakarta: Bumi Aksara.

Moekijat, 2006, Latihan dan pengembangan Sumber daya Manusia, cetakan kelima Mandar Maju, Bandung.

Panji Anoraga. 2005. Psikologi kerja. Jakarta: PT. Rineka Cipta

Sugiyono. 2012. Statistika untuk Penelitian. Bandung : Alfabeta.

Suharsimi Arikunto. 2006. Prosedur Penelitian Suatu Pendekatan Praktek. Jakarta: Rineka Cipta.

Sinungan , 2008. Produktivitas Apa dan Bagaimana , Jakarta: Bumi Askara

Soepomo, Imam, 2006 Pengantar Hukum Perburuhan, Jakarta: Djambatan

Tri Joko, 2006, Strategi Belajar Mengajar, Pustaka Prasetya Bandun 